\title{
GAMBARAN PENGETAHUAN IBU HAMIL TENTANG BUKU KESEHATAN IBU DAN ANAK (KIA) DI BPS SULASMI SST RAJABASA BANDAR LAMPUNG
}

\author{
Nita Evrianasari \\ Prodi Kebidanan Universitas Malahayati Lampung \\ Email: sunarsih.unmal@yahoo.com
}

\begin{abstract}
Description of Pregnant Mother's Knowledge about Book of Mother's and Child Health (KIA) in BPS Sulasmi SST Rajabasa Bandar Lampung. Minister of Health of the Republic of Indonesia 284/ Menkes/ SK/ III/ 2004 about KIA Handbook, states KIA Handbook is a tool for early detection of the disorder or health problems of mothers and children, means of communication and outreach with information that is important for the mother and the family and society on maternal and child health services including reference and packages (standard) KIA services, nutrition, immunization and infant growth and development. The purpose of this study is known description knowledge of pregnant women about maternal and child health (KIA) in BPS Sulasmi SST Rajabasa Bandar Lampung 2014. This type of research is descriptive quantitative method. The location of research conducted at BPS Sulasmi SST Rajabasa Bandar Lampung in August till October 2014. The population in this study were pregnant women in BPS Sulasmi SST Rajabasa Bandar Lampung as many as 30 by the number of sample of 30 pregnant women. Sample retrieval technique used total population. This study use questionnaire as instrument. Variables used in this study is a single variable. Based on the calculation results of the calculation results obtained picture book knowledge of pregnant women about maternal and child health (KIA) in BPS Sulasmi SST Rajabasa Bandar Lampung. In good categories 5 people (16.7\%), enough category 18 people $(60.7 \%)$, less the category 7 people $(23.3 \%)$. This is affected because of their age and information / media. It is also desirable health workers to always fill the maternal and child health data completely and clearly so that the mother knows her health through health records in the book Mother and Child Health (KIA).
\end{abstract}

Keywords: Maternal, Knowledge, Books Maternal and Child Health (KIA).

Abstrak: Gambaran Pengetahuan Ibu Hamil tentang Buku Kesehatan Ibu dan Anak (KIA) di BPS Sulasmi SST Rajabasa Bandar Lampung. Keputusan Menteri Kesehatan Republik Indonesia 284/MENKES/SK/III/2004 tentang Buku KIA, menyatakan Buku KIA merupakan alat untuk mendeteksi secara dini adanya gangguan atau masalah kesehatan ibu dan anak, alat komunikasi dan penyuluhan dengan informasi yang penting bagi ibu dan keluarga dan masyarakat mengenai pelayanan kesehatan ibu dan anak termasuk rujukannya dan paket (standar) pelayanan KIA, gizi, imunisasi dan tumbuh kembang balita. Tujuan penelitian ini adalah diketahui gambaran pengetahuan ibu hamil tentang buku kesehatan ibu dan anak (KIA) di BPS Sulasmi SST Rajabasa Bandar Lampung Tahun 2014. Jenis penelitian yang digunakan adalah metode deskriptif kuantitatif. Lokasi penelitian dilaksanakan di BPS Sulasmi SST Rajabasa Bandar Lampung pada bulan Agustus s.d. Oktober 2014. Populasi dalam penelitian ini adalah ibu hamil di BPS Sulasmi SST Rajabasa Bandar Lampung sebanyak 30 dengan jumlah sampel 30 ibu hamil. Tehnik pengambilan sampel yang digunakan total populasi. Instrumen yang didunakan adalah kuesioner. Variabel yang digunakan dalam penelitian ini adalah variabel tunggal. Hasil perhitungan berdasarkan hasil perhitungan diperoleh hasil gambaran pengetahuan ibu hamil tentang buku kesehatan ibu dan anak (KIA) di BPS Sulasmi SST Rajabasa Bandar Lampung. Pada kategori baik 5 orang $(16,7 \%)$, kategori cukup 18 orang $(60,7 \%)$, kategori kurang orang $7(23,3 \%)$. Hal ini dipengaruhi karena umur dan informasi/media massa. Diharapkan juga petugas kesehatan untuk selalu mengisi data kesehatan ibu dan anak dengan lengkap dan jelas supaya ibu mengetahui kesehatannya melalui catatan-catatan kesehatan yang ada dalam buku Kesehatan Ibu dan Anak (KIA).

Kata kunci: Pengetahuan, Ibu hamil, Buku Kesehatan Ibu dan Anak (KIA).

Berdasarkan Survei Demografi dan ibu hamil. Tingginya angka kematian ibu di Kesehatan Indonesia (SDKI) tahun 2012, angka Indonesia menempatkan upaya penurunan AKI kematian ibu (AKI) merupakan salah satu sebagai program prioritas. Keadaan ibu sejak indikator untuk melihat derajat kesehatan pada pra-hamil sangat berpengaruh pada kehamilanya. 
Pada tahun 2012 AKI mengalami peningkatan 359/100.000 kelahiran hidup dan Angka kematian bayi (AKB) 30 per 1000 kelahiran hidup. Sedangkan target millennium development goals (MDG's) pada tahun 2015 adalah AKI 102/100.000 angka kelahiran hidup dan AKB 23/1.000 angka kelahiran hidup.

Buku Kesehatan Ibu dan Anak (KIA) merupakan buku pedoman yang dimiliki oleh ibu dan anak yang berisi informasi dan catatan kesehatan ibu dan anak yang merupakan satusatunya alat pencatatan pelayanan kesehatan ibu dan anak sejak ibu hamil, melahirkan dan selama masa nifas hingga bayi yang dilahirkan berusia 5 tahun (Kemenkes RI, 2009). Penggunaan buku KIA merupakan salah satu strategi pemberdayaan masyarakat terutama keluarga untuk memelihara kesehatan dan mendapatkan pelayanan kesehatan yang berkualitas (Kemenkes RI, 2013).

Penerapan buku KIA pada semua fasilitas kesehatan diharapkan dengan meningkatkan pengetahuan dan pemahaman ibu hamil sehingga komplikasi yang mungkin dalam masa kehamilan terdeteksi sedini mungkin sesuai dengan tujuan pelayanan antenatal yaitu mencegah adanya komplikasi obstetrik dan memastikan bahwa komplikasi dapat dideteksi dan ditangani secara memadai (Saifuddin, 2009).

Dari data kunjungan ibu hamil di BPS Sulasmi, SST pada tahun 2014 mencapai $432 \mathrm{ibu}$ hamil. Berdasarkaan hasil presurvey yang telah dilakukan di BPS Sulasmi pada tanggal 30 Agustus 2014 didapatkan jumlah ibu hamil pada bulan Agustus sebanyak 25 ibu hamil, kemudian setelah dilakukan wawancara dan kuesioner yang berisi pengertian dan manfaat buku KIA terhadap 9 ibu hamil yang melakukan ANC pada saat tanggal presurvey terdapat 4 ibu hamil yang mengetahui tentang Buku Kesehatan Ibu dan Anak (KIA) dan 5 ibu hamil kurang mengetahui tentang Buku KIA.

Berdasarkan latar belakang di atas maka peneliti tertarik untuk mengambil judul "Gambaran Pengetahuan Ibu hamil tentang Buku Kesehatan Ibu dan Anak (KIA) di BPS Sulasmi, S.ST Rajabasa Indah Bandar Lampung tahun 2014".

\section{METODE PENELITIAN}

Penelitian ini menggunakan jenis penelitian kuantitatif dengan rancangan penelitian deskriptif. Penelitian dilakukan pada bulan Agustus s.d Oktober 2014. Tempat penelitian ini adalah BPS Sulasmi, SST Rajabasa Indah Bandar Lampung. Populasi dalam penelitian ini adalah seluruh ibu hamil yang ada di BPS Sulasmi Rajabasa Indah Bandar Lampung dari bulan Agustus sampai September tahun 2014. Sampel dalam penelitian ini adalah sebagian ibu hamil yang ada di BPS Sulasmi Rajabasa Indah Bandar Lampung dari bulan Agustus sampai September tahun 2014 yang berjumlah 38 orang. Pengambilan sampel dengan teknik Accidental Sampling.

Variabel dalam penelitian adalah variabel tunggal yaitu pengetahuan ibu hamil tentang buku kesehatan ibu dan anak (KIA), dengan sub variabel adalah gambaran pengetahuan ibu hamil tentang buku kesehatan ibu dan anak (KIA).

\section{HASIL}

\section{A. Karakteristik Responden}

Tabel 1. Karakteristik Responden Berdasarkan Usia Ibu Hamil

\begin{tabular}{ccc}
\hline Usia & Jumlah & Persentase \\
\hline$<20$ & 3 & $10 \%$ \\
\hline $20-40$ & 27 & $90 \%$ \\
\hline$>40$ & 0 & $0 \%$ \\
\hline Total & 30 & $100 \%$ \\
\hline
\end{tabular}

Tabel 2. Karakteristik Responden Berdasarkan Pendidikan

\begin{tabular}{ccc}
\hline Pendidikan & Jumlah & Persentase \\
\hline SD & 3 & $10 \%$ \\
\hline SMP & 8 & $26,7 \%$ \\
\hline SMA & 13 & $43,3 \%$ \\
\hline PT & 6 & $20 \%$ \\
\hline Total & 30 & $100 \%$ \\
\hline
\end{tabular}

Tabel 3. Karakteristik Responden Berdasarkan Pekerjaan

\begin{tabular}{ccc}
\hline Pekerjaan & Jumlah & Persentase \\
\hline Pedagang & 4 & $13,3 \%$ \\
\hline Wiraswsta & 6 & $20 \%$ \\
\hline IRT & 19 & $63,4 \%$ \\
\hline Karyawan & 1 & $3,3 \%$ \\
\hline Total & 30 & $100 \%$ \\
\hline
\end{tabular}

\section{B. Analisis Univariat}

Tabel 4. Distribusi Frekuensi Gambaran Pengetahuan Ibu Hamil tentang Buku Kesehatan Ibu dan Anak (KIA)

\begin{tabular}{llcc}
\hline No & Pengetahuan ibu hamil & Jlh & Persentase \\
\hline 1. & Baik & 5 & $16,7 \%$ \\
\hline 2. & Cukup & 18 & $60,7 \%$ \\
\hline 3. & Kurang & 7 & $23,3 \%$ \\
\hline & Jumlah & 30 & $100,0 \%$ \\
\hline
\end{tabular}




\section{PEMBAHASAN}

Berdasarkan hasil penelitian dapat diketahui bahwa distribusi frekuensi gambaran pengetahuan ibu hamil tentang buku kesehatan ibu dan anak (KIA) lebih tinggi pada kategori cukup sebesar $18(60 \%)$ orang, pengetahuan kurang baik ada sebesar 7 orang $(23,3 \%)$. Dan kategori baik ada sebesar 5 orang $(16,7 \%)$. Jadi dapat disimpulkan bahwa pengetahuan ibu hamil tentang buku kesehatan ibu dan anak (KIA) di BPS Sulasmi, SST Rajabasa Indah Bandar Lampung Tahun 2014 yang tertinggi pada kategori Cukup yaitu sebanyak 18 orang $(60 \%)$.

Dari hasil penelitian didapatkan hasil responden dengan pendidikan SD sebanyak 3 orang $(10 \%)$, responden dengan pendidikan SMP sebanyak 8 orang $(26,7 \%)$, responden dengan pendidikan perguruan tinggi sebanyak 6 orang $(20 \%)$ dan responden yang tidak sekolah 0 orang $(0 \%)$.

Pendidikan adalah suatu usaha untuk mengembangkan kepribadian dan kemampuan di dalam dan di luar sekolah dan berlangsung seumur hidup. Pendidikan mempengaruhi proses belajar, semakin tinggi pendidikan seseorang semakin mudah orang tersebut untuk menerima informasi. Semakin banyak informasi yang masuk smakin banyak pula pengetahuan yang didapat tentang kesehatan (Notoatmodjo, 2007).

Pengetahuan adalah hasil penginderaan manusia, atau hasil tahu seseorang terhadap objek melalui indera yang dimilikinya. Dengan sendirinya, pada waktu penginderaan sambil menghasilkan pengetahuan oleh intensitas perhatian dan persepsi pada objek. Sebagian pengetahuan orang diperoleh melalui indera pendengaran (telinga) dan indera penglihatan (mata). Pengetahuan seseorang terhadap objek mempunyai intensitas atau tingkat yang berbeda. (Notoatmodjo, 2014).

Penelitian ini sejalan dengan penelitian Ayu Wiratih (2013) tentang tingkat pengetahuan ibu hamil tentang buku kesehatan ibu dan anak (KIA) di BPS Titik Desa Padas Kabupaten Tanon Sragen tahun 2013. Penelitian ini menggunakan metode penelitian deskriptif kuantitatif. Populasi dalam penelitian ini adalah ibu hamil di BPS Titik dengan jumlah sampel $30 \mathrm{ibu}$ hamil. Instrumen yang digunakan adalah kuesioner. Variabel yang digunakan adalah variabel tunggal. Berdasarkan hasil perhitungan diperoleh hasil kategori baik ada 6 responden $(20 \%)$, kategori cukup ada 21 responden (70\%) responden, kategori kurang ada 3 responden $(10 \%)$. Jadi tingkat pengetahuan ibu hamil tentang buku kesehatan ibu dan anak (KIA) di BPS Titik Desa Padas Kabupaten Tanon Sragen kategori cukup.

Berdasarkan pembahasan di atas dapat diketahui bahwa pengetahuan ibu hamil tentang buku kesehatan ibu dan anak (KIA) di BPS Sulasmi, SST Rajabasa Indah Bandar Lampung adalah dalam kategori cukup. Hal ini dapat dilihat dari masih banyak ibu hamil yang kurang mengetahui tentang manfaat buku kesehatan ibu dan anak (KIA) dan isi dari buku kesehatan ibu dan anak (KIA). Salah satu penyebabnya adalah ibu hamil sudah diberikan buku pedoman berupa buku kesehatan ibu dan anak (KIA) tetapi kesadaran untuk menjaga, membawa buku KIA dan kesadaran ingin membaca buku KIA serta menanyakan apabila ada hal yang kurang mengerti sangatlah kurang.

Menurut peneliti hal ini dipengaruhi oleh umur dan informasi. Semakin bertambah umur seseorang akan semakin berkembang pula daya tangkap dan pola pikirnya, sehingga pengetahuan yang diperolehnya semakin membaik. Serta faktor dimana semakin banyak memperoleh informasi maka seseorang cenderung mempunyai pengetahuan yang lebih luas. Tetapi, pengetahuan tidak akan luas apabila sudah diberikan media pedoman tetapi kesadaran untuk memanfaatkan media pedoman masih sangat rendah. Masih kurangnya pengetahuan juga dikarenakan kurangnya informasi media masa/iklan dan informasi massal yang minim dari pemerintah untuk lebih mensosialisasikan pentingnya buku KIA karena kebanyakan ibu hanya mendapatkan informasi dari tenaga kesehatan setempat saja.

\section{SIMPULAN}

Distribusi frekuensi pengetahuan ibu hamil tentang buku kesehatan ibu dan anak (KIA) di BPS Sulasmi SST Rajabasa Bandar Lampung Tahun 2014 pada kategori kurang baik sebesar 7 orang $(23,3 \%)$, kategori baik sebesar 5 orang $(16,7 \%)$ dan pada kategori cukup sebanyak 18 orang $(60,7 \%)$.

\section{SARAN}

1. Bagi petugas kesehatan di BPS Sulasmi, SST Rajabasa Indah Bandar Lampung untuk meningkatkan upaya sosialisasi informasi tentang Buku Kesehatan Ibu dan Anak, manfaat buku kesehatan ibu dan anak serta isi buku kesehatan ibu dan anak (KIA) melalui penyuluhan menggunakan bahasa yang mudah dipahami dan selalu menyarankan ibu untuk selalu membawa 
buku kesehatan ibu dan anak (KIA) setiap melakukan Antenatal Care (ANC) dan juga menyarankan ibu untuk rajin membaca isi buku kesehatan ibu dan anak (KIA).

2. Petugas kesehatan di BPS Sulasmi, SST Rajabasa Indah Bandar Lampung diharapkan untuk selalu mengisi data kesehatan ibu dan anak dengan lengkap dan jelas supaya ibu mengetahui kesehatannya melalui catatancatatan kesehatan yang ada dalam Buku Kesehatan Ibu dan Anak (KIA).

3. Dapat melanjutkan penelitian ini dengan analisis yang lebih mendalam mengenai faktor-faktor yang mempengaruhi pengetahuan ibu hamil tentang buku kesehatan ibu dan anak (KIA).
4. Agar ibu hamil dapat meningkatkan kesadaran untuk membaca dan memahami isi dari buku kesehatan ibu dan anak (KIA). Ketika sudah diberi buku kesehatan ibu dan anak (KIA) dan diberi informasi tentang buku kesehatan ibu dan anak (KIA) hendaklah membacanya lagi di rumah dan tanyakan kepada petugas kesehatan apabila ada yang kurang mengerti. Hal ini supaya ibu-ibu mengerti pentingnya kesehatan ibu dan anak, persiapan menghadapi persalinan, tanda-tanda bahaya kehamilan, persalinan dan nifas serta cara merawat bayi baru lahir dan tahap perkembangannya. Sehingga ibu bisa langsung ke petugas kesehatan apabila ibu mengalami tanda-tanda bahaya atau lainnya.

\section{DAFTAR PUSTAKA}

Kemenkes RI. 2009. Petunjuk Teknis Penggunaan Buku Kesehatan Ibu dan anak (KIA). Jakarta. Kemenkes dan JICA.

Kemenkes RI. 2013. Buku Kesehatan Ibu dan anak (KIA). Jakarta. Kemenkes dan JICA.

Notoatmodjo, S. 2007. Penelitian Kesehatan. Jakarta. Rineka.

Notoatmodjo, S. 2014. Ilmu Perilaku Kesehatan. Jakarta. Rineka Cipta.

Saifuddin.2009. Buku Acuan Nasional Pelayanan Kesehatan Maternal dan Neonatal.
Jakarta. PT. Bina Pustaka Sarwono Prawirohardjo.

Badan Pusat Statistik. 2013. Survey Demografi dan Kesehatan INDONESIA 2012. Jakarta. BPS. BKKBN. Kemenkes.

Wiratih, A. 2013. Tingkat pengetahuan ibu hamil tentang buku kesehatan ibu dan anak (KIA) di BPS Titik Desa Padas Kabupaten Tanon Sragen. Surakarta. http://digilib.stikeskusumahusada.ac.id/do wnload.php?id $=508$ 